\title{
Hormone-stimulated secretion of luteinization factor in porcine granulosa cells
}

\author{
A Danišová, J Kolena \\ Slovak Academy of Sciences, Institute of Experimental Endocrinology, \\ Vlarska 3, 83306 Bratislava, CSFR
}

(Received 2 September 1991; accepted 11 March 1992)

\begin{abstract}
Summary - Luteinization stimulator (LS) is an intrafollicular compound which was shown to be released by granulosa cells under in vitro conditions with stimulatory effects on immature granulosa cell differentiation. This study was undertaken to determine the effects of various endocrine agents which are involved in the regulation of ovarian function on LS secretion by porcine granulosa cells isolated from 5-8-mm follicles (LGC). Cell conditioned media (CM) obtained after the 4-day culture of LGC were tested in the culture of immature (small) granulosa cells (SGC). The activity of LS released into the LGC conditioned medium was estimated by measuring progesterone $\left(P_{4}\right)$ produced by SGC in the presence of $\mathrm{CM}$. Stimulation of $\mathrm{P}_{4}$ secretion was observed after addition of media from cultures treated by LHRH $\left(10^{-4}\right.$ mol..$\left.^{-1}\right)$, epinephrine $\left(10^{-5} \mathrm{~mol}^{-1} \mathrm{I}^{-1}\right)$, LH $\left(1 \mu \mathrm{g} \cdot \mathrm{ml}^{-1}\right)$, dbcAMP $\left(0.5\right.$ and $\left.2.0 \mu \mathrm{g} \cdot \mathrm{ml}^{-1}\right)$ or insulin $\left(1.0-5.0 \mu \mathrm{g} \cdot \mathrm{ml}^{-1}\right)$. Norepinephrine $\left(10^{-5}\right.$ and $\left.10^{-7} \mathrm{~mol}^{-1} \mathrm{l}^{-1}\right)$, estradiol $\left(0.1\right.$ and $\left.1.0 \mu \mathrm{g} \cdot \mathrm{ml}^{-1}\right)$ and prolactin $\left(0.1\right.$ and $\left.1.0 \mu \mathrm{g} \cdot \mathrm{ml}^{-1}\right)$ did not change steroidogenic activity of $\mathrm{CM}$. Epinephrine and norepinephrine $\left(10^{-5}\right.$ and $\left.10^{-7} \mathrm{~mol}^{-1}\right)$, LH $\left(1 \mu \mathrm{g} \cdot \mathrm{ml}^{-1}\right)$, dbcAMP $\left(2.0 \mu \mathrm{g} \cdot \mathrm{ml}^{-1}\right)$ and estradiol $\left(1 \mu \mathrm{g} \cdot \mathrm{ml}^{-1}\right)$ alone enhanced $P_{4}$ production by SGC, whereas LHRH $\left(10^{-3}\right.$ and $10^{-4}$ mol. I $\left.^{-1}\right)$, insulin $\left(1.0-5.0 \mu \mathrm{g} \cdot \mathrm{ml}^{-1}\right)$ and prolactin $\left(0.1\right.$ and $\left.1.0 \mu \mathrm{g} \cdot \mathrm{ml}^{-1}\right)$ did not have any effect. These observations suggest that the process of LS secretion in developing follicles is subject to a specific hormonal control.
\end{abstract}

luteinization stimulator / progesterone biosynthesis / granulosa cell / pig

Résumé - Stimulation hormonale de la sécrétion d'un facteur de lutéinisation par les cellules de la granulosa de porc. Le facteur stimulateur de la lutéinisation (LS) est un composé intrafolliculaire sécrété par les cellules de la granulosa in vitro qui stimule aussi la différenciation des cellules de la granulosa. Cette étude a pour but de déterminer l'effet des divers effecteurs hormonaux impliqués dans la régulation de la fonction ovarienne sur la sécrétion de $L S$ par les cellules de la granulosa du porc (LGC) isolées à partir des follicules de 5-8 $\mathrm{m}$. L'effet d'un milieu conditionné obtenu après $4 j$ de culture des LGC a été testé sur des cultures de petites cellules de granulosa immatures (SGC). L'activité du LS présent dans le milieu conditionné a été évaluée par la production de progestérone $\left(P_{4}\right)$ par les SGC incubées dans ce milieu. Une stimulation de la production de $P_{4}$ a été observée après l'addition de milieu de culture des cellules LGC traitées par la LHRH $\left(10^{-4}\right.$ mol.t $\left.{ }^{-1}\right)$, l'adrénaline $\left(10^{-5}\right.$ mol. - $^{-1}$, la $\mathrm{LH}\left(1 \mu \mathrm{g} \cdot \mathrm{mt}^{-1}\right)$, le dbcAMPc $\left(0,5\right.$ et $\left.2,0 \mu \mathrm{g} \cdot \mathrm{ml}^{-1}\right)$ ou l'insuline $\left(1,0-5,0 \mu \mathrm{g} \cdot \mathrm{mr}^{-1}\right)$. La noradrénaline $\left(10^{-5}\right.$ et $\left.10^{-7} \mathrm{~mol}^{-1}\right)$, l'cestradiol $\left(0,1\right.$ et $\left.1,0 \mu \mathrm{g} \cdot \mathrm{mr}^{-1}\right)$ et la prolactine $\left(0,1 \mathrm{et} 1,0 \mu \mathrm{g} \cdot \mathrm{mr}^{-1}\right)$ ne modifient pas l'activité stéroïdogénique du milieu conditionné. Un effet direct sur la synthèse du $\mathrm{P}_{4}$ par les $S G C$ a été observé pour certains facteurs comme l'adrénaline et la noradrénaline $\left(10^{-5}\right.$ et $10^{-7}$ 
mol..$^{-1}$ ), la $L H\left(1 \mu g . m r^{-1}\right)$, dbcAMPc $\left(2 \mu g . m r^{-1}\right)$ et l'œestradiol $\left(1 \mu g . m r^{-1}\right)$, mais pas pour la $\mathrm{LHRH}\left(10^{-3}\right.$ et $10^{-4}$ mol..$\left.^{-1}\right)$, linsuline $\left(1,0\right.$ et $\left.5,0 \mu \mathrm{g} \cdot \mathrm{mr}^{-1}\right)$ et la prolactine $\left(0,1 \mathrm{et} 1,0 \mu \mathrm{g} \cdot \mathrm{ml}^{-1}\right)$. Ces résultats suggèrent que la sécrétion de $L S$ par les follicules en cours de croissance est soumise à un contrôle hormonal spécifique.

\section{stimulateur de lutéinisation / biosynthèse de progestérone / cellules de granulosa / porc}

\section{INTRODUCTION}

It is well established that FSH and LH are the major regulators of granulosa cell differentiation. The action of these pituitary gonadotropins is modulated by other peptide hormones, neurotransmitters, steroid hormones, growth factors, components of extracellular matrix and some nonsteroidal factors produced locally by the ovary (Channing et al, 1982; Schomberg et al, 1983). A luteinization stimulator (LS) which stimulates the luteinization process of granulosa cells is involved in the control of maturation and development of ovarian follicles. LS was demonstrated in follicular fluid isolated from preovulatory follicles of various species, while a low stimulatory activity was found in follicular fluid from small (SFF) or atretic follicles (Younglai, 1972; Ledwitz-Rigby and Rigby, 1979; Channing et al, 1982; Kolena and Channing, 1985). Follicular fluid from large follicles (LFF) has been reported to enhance basal as well as FSH-stimulated progesterone $\left(P_{4}\right)$ secretion and to induce $\mathrm{LH} / \mathrm{hCG}$ receptor synthesis. The same stimulatory effects in immature granulosa cell culture were observed with partially purified stimulatory activity of follicular fluid from large follicles (Kolena and Channing, 1985).

It was also found that spent conditioned media from porcine granulosa cells culture contain a factor which meets the criteria for LS (Śeböková et al, 1987). Granulosa cells isolated from large porcine follicles showed an increased ability to release LS in comparison to granulosa cells isolated from small follicles.
Due to the known modulatory effect of various endocrine compounds on the granulosa cells responsiveness to $\mathrm{FSH}$ it was therefore of interest to determine the action of these agents on LS production by granulosa cells. In the present study we have investigated the influence of LHRH which was found to be involved in the upand down-regulation control of granulosa cell steroidogenesis (Clark, 1983; SheelaRani et al, 1983a) and the action of catecholamines, epinephrine and norepinephrine, which have been shown to act synergistically with gonadotropins with respect to granulosa cell responsiveness (SheelaRani et al, 1983b). Furthermore, we attempted to investigate the role of estradiol and prolactin, which are considered to be important factors involved in ovarian granulosa cell function (Hsueh, 1986; McNeilly et al, 1982). Finally, we focused on the effect of insulin which is known to act at various steps of granulosa cell steroidogenesis (Davoren and Hsueh, 1984; Veldhuis and Kolp, 1985; Veldhuis et al, 1986). Because available data for isolation of pure active LS are lacking, we used a biological test for studying the regulation of LS secretion by granulosa cells in culture.

\section{MATERIALS AND METHODS}

\section{Materials}

Porcine FSH (FSH-F-1) and rat LH (LH-RP-I) were generously supplied by NIAMDD, NIH (Bethesda, MD, USA), ovine prolactin (oPRL-18) by NIADDK-NIH (Bethesda, MD, USA). LH-RH (Op 
103) was obtained from Hoechst AG (Frankfurt, Germany). Insulin, thyroxin, estradiol, $\mathrm{N}^{6}, \mathrm{O}^{2}$. dibutyryl adenosine-3'-5'- cyclic monophosphate (dbcAMP), L-epinephrine bitartrate, norepinephrine and Medium 199 with Earle's salts were purchased from Sigma Chemical Co (St Louis, MO, USA). Fungizone (amphotericin B) was from Serva (Heidelberg, Germany), penicillin and streptomycin from Spofa (Prague, CSFR). [125I]-Progesterone was obtained from the Institute of Radioecology and Exploitation of Nuclear Technique (Kosice, CSFR). Tissue culture multiwell plates (Cat No 76-063-05) were purchased from Flow Labs (Rockwille, MD, USA).

\section{Cell culture}

Porcine ovaries from approximately 6-month-old animals were obtained at a local slaughterhouse and transported to the laboratory in physiological saline plus antibiotics on ice. Granulosa cells (LGC) were harvested from 5-8-mm ovarian follicles as previously described (Kolena and Channing, 1972). LGC were washed twice in serum-free media and incubated at a density of $4.0-6.0 \times 10^{6}$ viable cells per $\mathrm{ml}$. Cell viability was estimated by counting with $0.06 \%$ trypan blue in a hemocytometer. LGC were cultured in a volume of $0.5 \mathrm{ml}$ at $37^{\circ} \mathrm{C}$ for 4 days in an atmosphere of $5 \% \mathrm{CO}_{2}, 95 \%$ air, using tissue culture multiwell plates containing Medium 199 with Earle's salts and Hepes buffer (250 mmol. $\left.\right|^{-1}$ ); the medium was changed by a fresh batch after 48 hours. The culture medium was supplemented with L-glutamine (1 mmol. $\left.\mathrm{I}^{-1}\right)$, porcine FSH (1 $\left.\mathrm{mU} \cdot \mathrm{ml}^{-1}\right)$; thyroxine $(0.1$ mmol..$\left.^{-1}\right)$, insulin $\left(0.04 \mu \mathrm{g} . \mathrm{ml}^{-1}\right)$ and the antibiotics fungizone $\left(0.25 \mu \mathrm{g} \cdot \mathrm{ml}^{-1}\right)$, penicillin (100 U. $\left.\mathrm{ml}^{-1}\right)$ and streptomycin $\left(100 \mu \mathrm{g} \cdot \mathrm{ml}^{-1}\right)$. The culture medium was supplemented with $10 \%$ pig serum for the first 2 days and with $5 \%$ pig serum for the remaining 2 days of culture (Kolena and Channing, 1985). The cells were cultured over 4 days in the absence or presence of specific agents. At the end of incubation, granulosa cell conditioned media (CM) were obtained from LGC and stored frozen at $-20^{\circ} \mathrm{C}$. The activity of CMs was determined by adding them to the cultures of granulosa cells isolated from small (1-2 $\mathrm{mm}$ ) follicles (SGC). SGC were cultured in the same experimental conditions as described above for LGC. During the first $48 \mathrm{~h}$ the cells were maintained in the hormone (FSH + insulin + thyroxin; see above) supplemented control medium, then the medium was replaced by the media containing specific agents or by various dilutions of LGC conditioned media and left for an additional 2 days. At the end of the incubation period, the media were collected and stored frozen at $-20^{\circ} \mathrm{C}$ until assayed for progesterone. Follicular fluid was collected from 6-12 mm large follicles (LFF) by aspiration and centrifugation at $1000 \mathrm{~g}$ for $15 \mathrm{~min}$.

\section{Progesterone assay}

$\mathrm{P}_{4}$ in culture media was quantified by $\left.\left[{ }^{125}\right]\right]-$ progesterone radioimmunoassay using specific antiserum against 11-OH-progesterone succinyl-BSA (kindly donated by Dr Tománek, Research Insitute of Animal Production, Prague, CSFR) without extraction (Kolena and Channing, 1985).

\section{Statistics}

The results from experiments run in quadruplicate were expressed as mean \pm SEM. Statistical significance was analyzed by Student's $t$-test.

\section{RESULTS}

Figure 1 presents bioactivity of conditioned media after the LHRH, epinephrine and norepinephrine treatment. Control conditioned medium from LGC culture (CM-C) stimulated SGC progesterone $\left(\mathrm{P}_{4}\right)$ production $(P<0.001)$. LHRH alone in either of 2 concentrations did not alter $\mathrm{P}_{4}$ synthesis by SGC. A significant stimulatory effect on $\mathrm{P}_{4}$ production in comparison with $\mathrm{CM}-\mathrm{C}$ was observed by $\mathrm{CM}$-LHRH $\left(10^{-4}\right.$ mol..$\left.^{-1}\right)$ which increased $\mathrm{P}_{4}$ secretion by 1.5 -fold over CM-C levels $(P<0.005)$. This suggests that LHRH in the lower concentration is able to stimulate secretion of luteinization stimulator (LS) by granulosa cells. A 


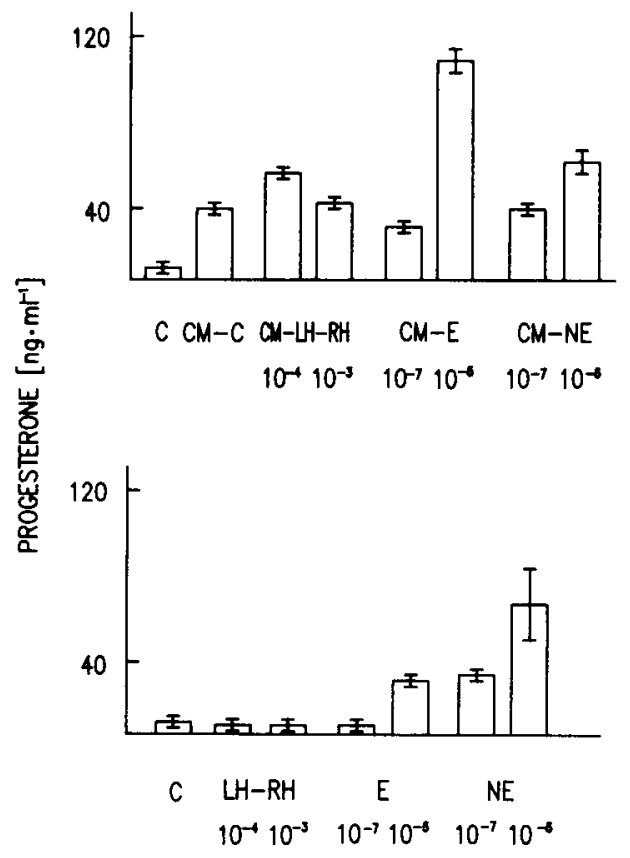

Fig 1. Progesterone production by immature granulosa cells (SGC) cultured in the presence of large granulosa cells spent conditioned media (CM). SGC $\left(4.6 \times 10^{6}\right.$ per $\left.\mathrm{ml}\right)$ were cultured for 2 days in complete medium with FSH $\left(1 \mathrm{mU} \cdot \mathrm{ml}^{-1}\right)+1\left(0.04 \mu \mathrm{g} \cdot \mathrm{ml}^{-1}\right)+\mathrm{T}_{4}(0.1$ mmol. $\left.I^{-1}\right)$. During the next 2 days SGC were incubated in the same medium (C), or (bottom panel) with LHRH, epinephrine (E), norepinephrine (NE) or (top panel) with $\mathrm{CM}$ replacing $50 \%$ of the cul-tured medium. CM were collected from 4-day cultures of LGC plated at a density $5.5 \times 10^{6}$ per $\mathrm{ml}$ treated by $\mathrm{FSH}+\mathrm{I}+\mathrm{T}_{4}$ (CM-C) and the same plus LHRH (CM-LHRH),E (CM-E) or NE (CM-NE). Values represent mean \pm SEM of 4 estimations repeated 3 times with essentially the same results.

higher effect on $\mathrm{P}_{4}$ production and accordingly or secretion of LS was observed in the presence of CM-epinephrine (CM-E $10^{-5}$ mol..$^{-1}$ ) which caused a 3.1 -fold increase on $\mathrm{P}_{4}$ synthesis over $\mathrm{CM}-\mathrm{C}$ levels $(P<0.001)$. Also the addition to the medium of epinephrine $(E)$ at $10^{-5}$ mol..$^{-1}$ produced an increase of $\mathrm{P}_{4}$ production $(P<0.005)$ but this effect was lower than that produced by $\mathrm{CM}-\mathrm{E} 10^{-5}$ mol. $\mathrm{I}^{-1}$ $(P<0.001)$. On the other hand, the steroidogenic effect of CM-norepinephrine (CM$\mathrm{NE}$ ) was probably due to the effect of norepinephrine (NE) alone which was able to enhance $\mathrm{P}_{4}$ synthesis by $\mathrm{SGC}$ to the same extent as the same concentration of CM-NE.

As shown in figure 2, $\mathrm{LH}\left(1 \mu \mathrm{g} \cdot \mathrm{ml}^{-1}\right)$ and dbcAMP $\left(2.0 \mu \mathrm{g} \cdot \mathrm{ml}^{-1}\right)$ significantly en-

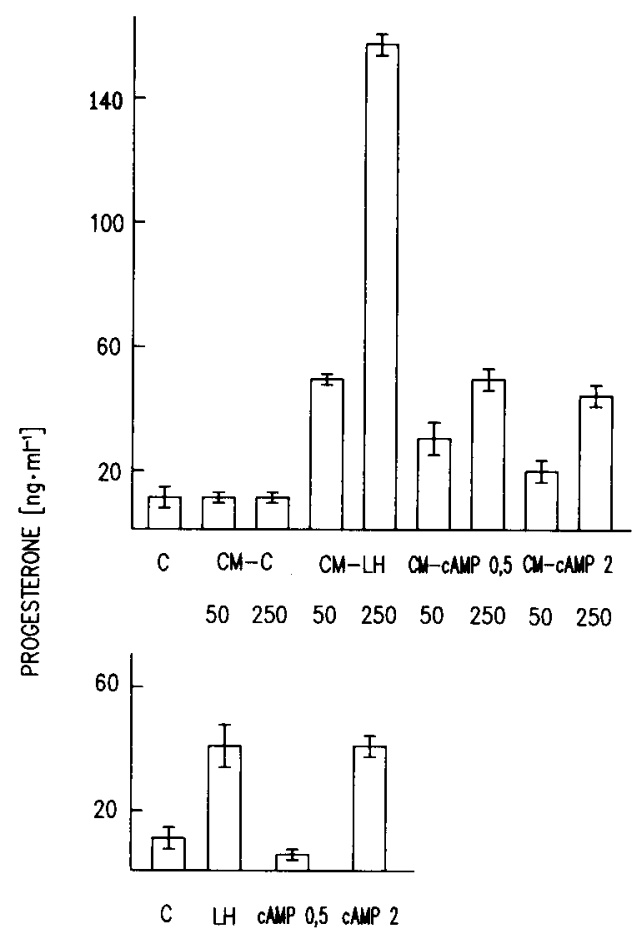

Fig 2. Effects of granulosa cell conditioned media on progesterone accumulation by SGC $\left(\mathrm{m} \pm\right.$ SEM). SGC $\left(4.2 \times 10^{6}\right.$ per $\left.\mathrm{ml}\right)$ were cultured as described in legend to figure 1 without (C) or with LH $\left(1 \mu \mathrm{g} \cdot \mathrm{ml}^{-1}\right)$, dbcAMP (0.5 and 2.0 $\mu \mathrm{g} \cdot \mathrm{ml}^{-1}$ ) (bottom panel) and $\mathrm{CM}$ (top panel), $\mathrm{CM}$ replacing $10 \%$ (CM-LH 50, CM-CAMP 50 ) or $50 \%$ (CM-LH 250, CM-cAMP 250) of the respective culture medium were generated by LGC $\left(4.2 \times 10^{6}\right.$ per $\left.\mathrm{ml}\right)$ cultured without $(\mathrm{CM}-\mathrm{C})$ or with the indicated agents. 
hanced $\mathrm{P}_{4}$ production by SGC. Treatment of SGC with conditioned media resulted in a 6.2-fold increase $(P<0.001)$ for $50 \mu \mathrm{l}$ of CM-LH and a 16-fold increase $(P<0.001)$ for $250 \mu \mathrm{l}$ of $\mathrm{CM}-\mathrm{LH}$ in comparison to cells cultured in the presence of CM-C. This indicates a great ability of $\mathrm{LH}$ to stimulate the secretion of LS by granulosa cells. Moreover, conditioned media from cultures treated by dbcAMP (CM-dbcAMP 0.5 $\mu \mathrm{g} \cdot \mathrm{ml}^{-1}$ and CM-dbcAMP $2.0 \mu \mathrm{g} \cdot \mathrm{ml}^{-1}$ ) enhanced $\mathrm{P}_{4}$ production by SGC $(P<0.05$; $P<0.005)$. These experiments suggest that dbcAMP enhances the release of LS into the culture medium.

The dose-response relationship of the effects of insulin upon LS secretion is illus-

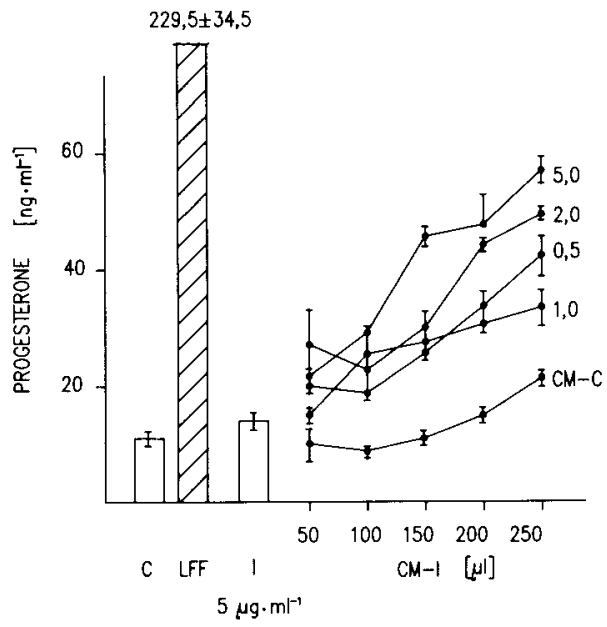

Fig 3. Direct effect of fluid of large follicles (LFF), insulin (I) and dose-dependent effects of granulosa cell conditioned media on progesterone secretion by SGC ( $m \pm$ SEM). SGC (4.6 $\times$ $10^{6}$ per $\mathrm{ml}$ ) were cultured as described in legend to figure 1 . For the last 2 days, increasing doses of insulin ( $\left.1.0-5.0 \mu \mathrm{g} / \mathrm{ml}^{-1}\right)$ and spent conditioned media (CM 50-250 $\mu$ ) were added. CM were obtained after a 4-day cultivation of LGC $\left(6.1 \times 10^{6} \mathrm{per} \mathrm{ml}\right)$ in culture medium supplemented by $\mathrm{FSH}+\mathrm{I}+\mathrm{T}_{4}(\mathrm{CM}-\mathrm{C})$ or were additionally treated by insulin at various concentrations (CM-I 1.0-5.0 $\mu \mathrm{g} \cdot \mathrm{ml}^{-1}$ ). trated in figure 3. SGC which served as control (C) were cultured in the presence of saturating concentrations of insulin $(0.04$ $\left.\mu \mathrm{g} \cdot \mathrm{ml}^{-1}\right)$. Further addition of insulin (1.0$5.0 \mu \mathrm{g} \cdot \mathrm{ml}^{-1}$ ) to the SGC culture did not significantly affect $\mathrm{P}_{4}$ production as compared with the corresponding control values; neither did the current treatment with increasing concentrations $(50-250 \mu \mathrm{l})$ of media CM-C obtained from a control LGC culture significantly change the level of SGC produced $\mathrm{P}_{4}$. However, conditioned media collected from the culture LGC treated by insulin $\left(1.0-5.0 \mu \mathrm{g} \cdot \mathrm{ml}^{-1}\right)$ had a significant stimulatory effect on $\mathrm{P}_{4}$ output, thus indicating enhanced LS secretion by granulosa cells. Using the highest concentration $250 \mu \mathrm{l}$ of media CM-I $2.0 \mu \mathrm{g} \cdot \mathrm{ml}^{-1}$ and $\mathrm{CM}-\mathrm{I}$ $5.0 \mu \mathrm{g} \cdot \mathrm{ml}^{-1}$ the enhancement was approximately 2.5 -fold $(P<0.005)$ and 3 -fold $(P<$

Table I. Progesterone synthesis ( $m \pm$ SEM) by $S G C$ in response to the addition of spent conditioned media obtained after the incubation with estradiol.

\begin{tabular}{|c|c|c|c|}
\hline & $\begin{array}{l}\text { Treatment } \\
\left(\mu g . m r^{-1}\right)\end{array}$ & $\begin{array}{l}C M \\
(\mu l)\end{array}$ & $\begin{array}{l}\text { Progesterone } \\
\left(\text { ng. } m l^{-1}\right)\end{array}$ \\
\hline Control (C) & & & $14.6 \pm 1.76$ \\
\hline$E_{2}$ & 0.1 & & $34.9 \pm 2.86$ \\
\hline$E_{2}^{2}$ & 1.0 & & $64.3 \pm 3.15 \mathrm{a}$ \\
\hline CM-C & 0 & $\begin{array}{r}50 \\
250\end{array}$ & $\begin{array}{l}17.1 \pm 0.32 \\
29.9 \pm 1.34 a\end{array}$ \\
\hline $\mathrm{CM}-\mathrm{E}_{2}$ & 0.1 & $\begin{array}{r}50 \\
250\end{array}$ & $\begin{array}{l}23.0 \pm 2.42 \\
39.0 \pm 4.30\end{array}$ \\
\hline $\mathrm{CM}-\mathrm{E}_{2}$ & 1.0 & $\begin{array}{r}50 \\
250\end{array}$ & $\begin{array}{l}23.2 \pm 1.38 \\
24.8 \pm 1.04\end{array}$ \\
\hline
\end{tabular}

Cultures of SGC $\left(4.8 \times 10^{6} \mathrm{per} \mathrm{ml}\right)$ and LGC $\left(6.0 \times 10^{6}\right.$ per $\mathrm{ml}$ ) were run similarly as described in legend to $\mathrm{fi}$ gure 1. a Significant difference vs control cells $(0.005<$ $P<0.001$ ). Concentration of $E_{2}$ refers to the amount of $E_{2}$ added to the $S G C$ culture. Concentration of the $C M$ $E_{2}$ refers to the amount of $E_{2}$ added to the LGC culture prior to the addition of conditioned medium to the SGC culture. 
Table II. Steroidogenic activity of spent conditioned media in SGC culture after treatment with prolactin ( $m \pm S E M$ ).

\begin{tabular}{llrc}
\hline & $\begin{array}{c}\text { Treatment } \\
\left(\mu g . \mathrm{m}^{-1}\right)\end{array}$ & $\begin{array}{c}\mathrm{CM} \\
(\mu l)\end{array}$ & $\begin{array}{c}\text { Progesterone } \\
\left(\text { ng. } \mathrm{m}^{-1}\right)\end{array}$ \\
\hline Control (C) & & & $7.9 \pm 3.25$ \\
$\mathrm{Prl}$ & 0.1 & & $15.5 \pm 5.84$ \\
$\mathrm{Prl}$ & 1.0 & & $5.9 \pm 1.40$ \\
$\mathrm{CM}-\mathrm{C}$ & 0 & 50 & $16.8 \pm 4.03$ \\
& & 250 & $39.9 \pm 1.80^{\mathrm{a}}$ \\
$\mathrm{CM}-\mathrm{Prl}$ & 0.1 & 50 & $21.2 \pm 3.27$ \\
& & 250 & $39.9 \pm 1.80^{\mathrm{a}}$ \\
$\mathrm{CM}-\mathrm{Prl}$ & 1.0 & 50 & $13.5 \pm 2.95$ \\
& & 250 & $36.1 \pm 2.27^{\mathrm{b}}$ \\
& & & \\
\hline
\end{tabular}

SCG $\left(4.6 \times 10^{6}\right.$ per $\left.\mathrm{ml}\right)$ were cultured in the presence of prolactin (Prl) or spent conditioned media ( $\mathrm{CM})$ from LGC $\left(5.5 \times 10^{6}\right.$ per $\left.\mathrm{ml}\right)$ culture without or with this hormone. a Significant difference vs control cells $(P<0.001)$. b Significant differences vs hormone treated cells $(0.02<P<0.001)$. Concentration of Pri refers to the amount of $\mathrm{Prl}$ added to the SGC culture. Concentration of $\mathrm{CM}-\mathrm{Prl}$ refers to the amount of $\mathrm{Prl}$ added to the LGC culture prior to the addition of the conditioned medium to the SGC culture.

$0.001)$ respectively when compared with CM-C. Maximal stimulation of $P_{4}$ release $(P<0.001)$ was achieved by follicular fluid isolated from large follicles (LFF) used in dilution $1+3$ of the total culture volume. LFF increased $P_{4}$ synthesis 11.5 -fold over CM-C levels $(P<0.001)$. Similar effects of LFF on SGC were observed in all experiments.

The effects of estradiol and prolactin on the LS secretion by granulosa cells is shown in table I and table II. Estradiol at the highest concentration $\left(1 \mu \mathrm{g} \cdot \mathrm{ml}^{-1}\right)$ enhanced $\mathrm{P}_{4}$ synthesis by SGC $(P<0.001)$. Nevertheless, estradiol did not alter LS production as a low steroidogenic effect of spent conditioned media was observed in these experiments (table I). Prolactin at both concentrations used did not affect steroidogenesis by granulosa cells (table II). In comparison to the direct addition of prolactin to the culture, spent conditioned media stimulated $\mathrm{P}_{4}$ production $(0.02<P<$ $0.001)$. However, when compared with control conditioned media (CM-C) no stimulatory effect of $\mathrm{CM}-\mathrm{Prl}$ on $\mathrm{P}_{4}$ synthesis was observed. This allows the suggestion to be made that these hormones probably did not stimulate secretion of LS.

\section{DISCUSSION}

These studies demonstrate the ability of LHRH, epinephrine, LH, dbcAMP and insulin to stimulate the release of an active compound by granulosa cells harvested from 5-8-mm follicles (LGC). This substance stimulates production of $\mathrm{P}_{4}$ by immature granulosa cells (SGC). The most active was the medium from cells cultured in the presence of $\mathrm{LH}$. However, the strongest stimulatory effect on $\mathrm{P}_{4}$ synthesis by SGC was observed by follicular fluid isolated from large follicles (LFF) used in the dilution $1+3$.

Follicular fluid contains various components stemming from follicular cells (Channing et al, 1982; Edwards, 1974; LedwitzRigby, 1987; Kolena and Seböková, 1986; Tonetta and diZerega, 1989). Stimulatory and inhibitory molecules in follicular fluid interact with receptors of granulosa cells and modulate the action of gonadotropins on the differentiation process of granulosa cells (Ledwitz-Rigby, 1987). In this respect, the strong stimulatory effect of LFF is due to the whole complex of factors released into it during the development of follicles.

Our results show that not all agents which increase $\mathrm{P}_{4}$ production are at the same time able to affect the production of LS. Estradiol and norepinephrine failed to enhance LS secretion although they elevated $P_{4}$ synthesis by granulosa cells in 
our experiments. It is well known that estradiol plays an important role in the differentiation of ovarian granulosa cells. Under in vitro conditions, estradiol enhances FSH-stimulated progesterone biosynthesis, CAMP production and increases FSHstimulated $\mathrm{LH}$ receptor formation in granulosa cells (Fanjul et al, 1984; Knecht et al, 1984). Similarly, stimulation by catecholamines of $\mathrm{P}_{4}$ synthesis in granulosa cells has previously been observed by others (Hudson et al, 1987; Webley et al, 1988).

On the other hand, $\mathrm{LHRH}$ which showed a stimulatory effect on the secretion of LS did not change $\mathrm{P}_{4}$ production by granulosa cells. It should be mentioned that LHRH changed the LS secretion at low concentrations only. LHRH had no effect at higher doses; the reason remains unknown. LHRH was found to have both stimulatory and inhibitory effects on granulosa cell steroidogenesis (Clark, 1982; Jones et al, 1983; Sheela-Rani et al, 1983a). The response of granulosa cells to LHRH depended on the type of granulosa cells used and mainly on exposure time. With increasing time of cultivation, LHRH inhibited CAMP and $\mathrm{P}_{4}$ production induced by FSH and $\mathrm{LH}$.

The mechanism by which the above hormones modulate granulosa cell steroidogenesis is partly known. In contrast, the mechanism by which LS secretion is induced is not clear. The ability of some hormones to act on steroidogenesis of granulosa cells but not on the secretion of LS (NE, $E_{2}$ ) or vice versa ( $\mathrm{LHRH}$ ) allows us to suggest that different cell systems are involved in the regulation of $\mathrm{P}_{4}$ synthesis and in the synthesis of LS. As a rather rapid degradation of added hormones can be expected, their main role could be the triggering of cellular processes leading to LS secretion.

Prolactin is known to directly affect $\mathrm{P}_{4}$ synthesis by isolated granulosa cells. De- pending on the model system and the hormone dose, the effects of prolactin vary from stimulatory to inhibitory (McNatty et al, 1974; Veldhuis et al, 1980; Cutie and Andino, 1988). Veldhuis et al (1980) found that prolactin inhibits $P_{4}$ secretion by cells from large follicles. In our experiments, no effects on $\mathrm{P}_{4}$ production and LS secretion were observed during the cultivation of granulosa cells with prolactin. Our results suggest that under the in vitro conditions used, prolactin is probably not involved in the control of LS secretion. However, in vitro interactions of prolactin with a number of other factors cannot be excluded. Veldhuis and Hammond (1980) demonstrated that the effect of prolactin upon steroidogenesis changed during cultivation of granulosa cells from small follicles in the presence of estradiol.

Current data provide evidence for the ability of insulin to affect the production of LS by granulosa cells. This effect was dose-dependent with maximum stimulation at a concentration of $5 \mu \mathrm{g} \cdot \mathrm{ml}^{-1}$ insulin. In these supraphysiological concentration ranges, insulin can interact with receptors for insulin-like growth factor I (IGF I) (Dorrington et al, 1987). In view of this, we hypothesize that the action of insulin in our experiments could be mediated by IGF I receptors. Insulin is required for FSHmediated induction of $\mathrm{LH} / \mathrm{hCG}$ receptor formation and $\mathrm{P}_{4}$ secretion in porcine granulosa cells cultured in serum-containing medium (Channing et al, 1976; May and Schomberg, 1981). Insulin participates in the regulation of lipoprotein metabolism in granulosa cells; it increases the activity of enzymes involved in $\mathrm{P}_{4}$ biosynthesis and augments aromatase activity of granulosa cells (Davoren and Hsueh, 1984; Veldhuis and Kolp, 1985, Veldhuis et al, 1986). The dose-dependent response of granulosa cells to insulin is influenced by cell density, stage of follicular maturation and by the presence of other hormones involved in 
regulation of ovarian activity (Veldhuis and Kolp, 1985; Veldhuis et al, 1986; Dorrington et al, 1987).

Despite some initial evidence for the presence of LS in follicular fluid and granulosa cell-conditioned media, the identity of this molecule has not yet been established. On the basis of experiments in which the effect of LFF in granulosa cell culture was tested, it was supposed that LS is a heat labile protein dependent on lipids but not on steroids or other lowmolecular weight components of LFF (Šeböková and Kolena, 1987). Delipidation of LFF, precipitation with ethanol, heating to $40-60{ }^{\circ} \mathrm{C}$ or freezing to $-70{ }^{\circ} \mathrm{C}$ reduced the stimulatory potency of LFF. The molecular weight of partially purified stimulatory activity obtained by Kolena and Channing (1985) from LFF was about 28000 . Further purification of LFF leads to the decrease of its stimulatory activity, probably because of the loss of some stabilizing substances which were dissociated during purification (Kolena and Channing, 1985). Initial purification of the LS was reported by Bar-Ami and Channing (1988) The purified LFF fraction increased $\mathrm{FSH}$ induced 125I-hCG and secretion of $\mathrm{P}_{4}$ by granulosa cells. The authors suggested that the LFF stimulatory activity might be ascribed to one or more proteins.

Mondschein et al (1989) hypothesized that the stimulatory effect of LFF might involve IGFs. These authors reported that $P_{4}$ production by granulosa cells cultured with LFF was inhibited by the anti-IGF-I antibody by $53 \%$. Anti-IGF-I antibody, however, was not able to completely block the stimulatory effect of LFF. In addition, the effects of antiIGF-I antibody were negligible in granulosa cell cultures treated by SFF which contains substantial quantities of IGFs. Furthermore, estradiol which is a stimulator of IGF I secretion (Hsu and Hammond, 1987) did not affect the bioactivity of conditioned media in our experiments.
In biological fluids, IGF peptides are associated with IGF-binding proteins (IGFBPs). A complex pattern of IGF-BPs with different molecular sizes was detected in follicular fluid and ovarian-cell conditioned media (for review see Hammond et al, 1991). It was shown that FSH and CAMP agonists inhibited both basal and insulin/ IGF-stimulated production of IGF-BP-2 and IGF-BP-3 by granulosa cells isolated from 4-6 mm follicles (Grimes et al, 1991). In contrast, dbcAMP stimulated LS secretion by LGC in our experiments. Recently, Ricciarelli et al (1991) demonstrated stimulatory effect of estradiol on rat thecainterstitial cell IGF-BP-2 gene expression. IGF-BP-1 which was shown to be produced by granulosa-luteal cells (Jalkanen et al, 1989) is present in large amounts in amniotic fluid (Brewer et al, 1988), but was not detected in porcine ovarian follicular fluid (Mondschein et al, 1991). Interestingly, we have not observed stimulatory effects of porcine amniotic fluid on progesterone production by $S G C$ in culture (unpublished observations). Furthermore, Lewitt and Baxter (1991) revealed a stimulatory effect of cytochalasin $B$ and an inhibitory effect of insulin on IGF-BP-1 production by HepG2 cells. Cytochalasin B did not affect the secretion of LS by granulosa cells isolated from large follicles in our experiments (Danisová and Kolena, 1991). In contrast, a strong stimulatory effect of insulin on LS secretion was demonstrated in the present study. In conclusion, our data do not support the hypothesis that LS could be identical with IGF-BPs.

Recently, a steroidogenic-inducing protein (SIP) was isolated from human follicular fluid (Khan et al, 1990). SIP stimulated corticosteroid production by adrenal cells, testosterone production by Leydig cells, and production of $\mathrm{P}_{4}$ by human granulosalutein cells under the basal conditions or after the hCG treatment. It was shown that the stimulatory effect of SIP on steroido- 
genesis was additive with the effect of CAMP, suggesting that SIP does not act by increasing cAMP level. In contrast to these results, Adashi et al (1986) reported that IGF-I stimulated CAMP secretion by granulosa cells. However, a stimulatory effect of LFF on $\mathrm{P}_{4}$ production by granulosa cells was not accompanied by an elevation of cAMP levels in our experiments (unpublished data). Khan et al (1990) have also observed that the stimulatory activity of SIP on steroid production by cells can be blocked by a specific inhibitor of steroidogenesis, aminogluthetimide; consistent with these findings, aminogluthetimide decreased stimulatory activity of granulosa cell conditioned media in our studies (data not shown). Finally, Khan et al (1990) have shown that human granulosa-lutein cell culture media have similar effects on testosterone production by Leydig cells to SIP. It is possible that SIP and LS are identical molecules but we do not yet have direct evidence to substantiate this hypothesis.

\section{ACKNOWLEDGMENT}

This investigation received financial support from the Special Programme of Research. Development and Research Training in Human $\mathrm{Re}$ production, World Health Organization, granted to J Kolena.

\section{REFERENCES}

Adashi EY, Resnick CE, Svoboda ME, VanWyk JJ (1986) Somatomedin-C as an amplifier of follicle-stimulating hormone action: enhanced accumulation of adenosine $3^{\prime}-5^{\prime}$ monophosphate. Endocrinology 118, 149-155

Bar-Ami S, Channing CP (1988) Characterization of follicular fluid stimulatory factor upon FSH-induced granulosa cell differentiation. J Endocrinol Invest 11, 777-783

Brewer MT, Stetler GL, Squires CH, Thompson RC, Busby WH, Clemmons DR (1988) Clon- ing, characterization and expression of a human insulin-like growth factor binding protein. Biochem Biophys Res Commun 152, 12891297

Channing CP, Tsai V, Sachs D (1976) Role of insulin, thyroxin and cortisol in luteinization of porcine granulosa cells grown in chemically defined media. Biol Reprod 15, 235-247

Channing CP, Anderson LD, Hoover DJ, Kolena $J$, Osteen KG, Pomerantz SH, Tanabe K (1982) The role of nonsteroidal regulators in control of oocyte and follicular maturation. Recent Prog Horm Res 38, 331-408

Clark MR (1982) Stimulation of progesterone and prostaglandin $\mathrm{E}$ accumulation by luteinizing hormone-releasing hormone (LHRH) and LHRH analogs in rat granulosa cells. Endocrinology 110, 146-152

Cutie E, Andino NA (1988) Prolactin inhibits the steroidogenesis in midfollicular phase human granulosa cells cultured in chemically defined medium. Fertil Steril 49, 632-637

Danisová A, Kolena J (1991) Involvement of the cytoskeleton components in the secretion of luteinization stimulator by porcine granulosa cells. Endocrine Regul 25, 207-210

Davoren JB, Hsueh AJW (1984) Insulin enhances FSH-stimulated steroidogenesis by cultured rat granulosa cells. Mol Cell Endocrinol 35, 97-105

Dorrington JH, Bendell JJ, Chuma A, Lobb DK (1987) Action of growth factors in the follicle. $\checkmark$ Steroid Biochem 27, 405-411

Edwards RG (1974) Follicular fluid. J Reprod Fertil 37, 189-219

Fanjul LF, Ruiz de Galarreta CM, Hsueh AJW (1984) Estrogen regulation of progestin biosynthetic enzymes in cultured rat granulosa cells. Biol Reprod 30, 903-912

Grimes R, Pearn J, Hammond J (1991) Insulinlike peptides stimulate, while cAMP agonists inhibit, production of insulin-like growth factor binding proteins by porcine granulosa cells in culture. 73rd Annu Meet Endocr Soc, June 19-22, Washington, abstr 339

Hammond JM, Mondschein JS, Samaras SE, Smith SA, Hagen DR (1991) The ovarian insulin-like growth factor system. J Reprod Fertil (suppl) 43, 199-208

Hsu CJ, Hammond JM (1987) Gonadotropins and estradiol stimulate immunoreactive insu- 
lin-like growth factor-l production by porcine granulosa cells in vitro. Endocrinology 120 , 198-207

Hsueh AJW (1986) Paracrine mechanisms involved in granulosa cell differentiation. Clin Endocrinol Metab 15, 117-134

Hudson KE, Wickings EJ, Hillier SG (1987) Effects of 2-hydroxyoestradiol, oestradiol and testosterone on $\mathrm{FSH}$-induction of catecholamine and gonadotropin-reponsive progesterone biosynthesis in rat granulosa cell cultures. J Steroid Biochem 28, 267-272

Jalkanen J, Suikkari AM, Koistinen R, Bützow R, Ritvos O, Seppälä M, Ranta T (1989) Regulation of insulin-like growth factor binding protein-1 production in human granulosa-luteal cells. J Clin Endocrinol Metab 69, 1174-1179

Jones PBC, Valk CA, Hsueh AJW (1983) Regulation of progestin biosynthetic enzymes in cultured rat granulosa cells: effects of prolactin, $\beta_{2}$-adrenergic agonist, human chorionic gonadotropin and gonatropin releasing hormone. Biol Reprod 29, 572-585

Khan SA, Keck C, Gudermann T, Nieschlag E (1990) Isolation of a protein from human ovarian follicular fluid which exerts major stimulatory effects on in vitro steroid production of testicular, ovarian and adrenal cells. Endocrinology 126, 3043-3052

Knecht M, Darbon JM, Ranta T, Baukal AJ, Catt KJ (1984) Estrogens enhance the adenosine 3',5'-monophosphate-mediated induction of follicle-stimulating hormone and luteinizing hormone receptors in rat granulosa cells. Endocrinology 115, 41-49

Kolena J, Channing CP (1972) Stimulatory effects of $\mathrm{LH}, \mathrm{FSH}$ and prostaglandins upon cyclic, 3'-5'-cAMP levels in porcine granulosa cells. Endocrinology 90, 1543-1550

Kolena J, Channing CP (1972) Stimulatory action of follicular fluid components on maturation of granulosa cells from small porcine follicles. Horm Res 21, 185-198

Kolena J, Seböková E (1986) Porcine follicular fluid containing water-soluble LH/hCG receptor. Arch Int Physiol Biochim 94, 261270

Ledwitz-Rigby $F$ (1987) Local regulation of granulosa cell maturation. J Steroid Biochem 27, 385-391
Ledwitz-Rigby F, Rigby BW (1979) Follicular fluid stimulation of steroidogenesis in immature granulosa cells in vitro. Mol Cell Endocrinol 14, 73-79

Lewitt MS, Baxter RC (1991) Cytochalasin B, stimulates insulin-like growth factor-binding protein-1 production by HepG2 cells. Mol Cell Endocrinol 77, 149-157

May JV, Schomberg DW (1981) Granulosa cell differentiation in vitro: effect of insulin on growth and functional integrity. Biol Reprod 25, 421-431

McNatty KP, Sawers RS, McNeilly AS (1974) A possible role for prolactin in control of steroid secretion by the human Graafian follicle. Nature (Lond) 250, 653-655

McNeilly AS, Glasier A, Jonassen J, Howie PW (1982) Evidence for direct inhibition of ovarian function by prolactin. $J$ Reprod Fertil 65 , 559-569

Mondschein JS, Canning SF, Miller DQ, Hammond JM (1989) Insulin-like growth factors (IGFs) as autocrine/paracrine regulators of granulosa cell differentiation and growth: studies with a neutralizing monocional antibody to IGF-I. Biol Reprod 40, 79-85

Mondschein JS, Etherton TD, Hammond JM (1991) Characterization of insulin-like growth factor-binding proteins of porcine ovarian follicular fluid. Biol Reprod 44, 315-320

Ricciarelli E, Hernandez ER, Hurwitz A, Kokia E, Rosenfeld RG, Schwander J, Adashi EY (1991) The ovarian expression of the antigonadotropic insulin-like growth factor binding protein-2 is theca-interstitial cell-selective: evidence for hormonal regulation. Endocrinology 129, 2266-2268

Schomberg DW, May JV, Mondschein JS (1983) Interactions between hormones and growth factors in the regulation of granulosa cell differentiation in vitro. J Steroid Biochem 19, 291-295

Seböková E, Kolena J (1987) Effect of follicular fluid on the maturation of porcine granulosa cells: stability of luteinization stimulator. Endocrinol Exp 21, 103-113

Seböková E, Danisová A, Kolena J (1987) Granulosa cells in culture are able to produce luteinization stimulatory factor. Endocrinol Exp 21, 3-12 
Sheela-Rani CS, Ekholm C, Billig H, Magnusson C, Hilensjö T (1983a) Biphasic effect of gonadotropin releasing hormone on progestin secretion by rat granulosa cells. Biol Reprod 28, 591-597

Sheela-Rani CS, Nodenstrom K, Norjavaara E, Ahren K (1983b) Development of cathecholamine responsiveness in granulosa cells from preovulatory rat follicles - dependence on preovulatory luteinizing hormone surge. Biol Reprod 29, 1021-1031

Tonetta SA, diZerega GS (1989) Intragonadal regulation of follicular maturation. Endocr Rev 10, 205-229

Veldhuis JD, Hammond JM (1980) Oestrogens regulate divergent effects of prolactin in the ovary. Nature (Lond) 284, 262-264

Veldhuis JD, Kolp LA (1985) Mechanisms subserving insulin's differentiating actions on progestin biosynthesis by ovarian cells: stud- ies with cultured swine granulosa cells. Endocrinology 116, 651-659

Veldhuis JD, Klase P, Hammond JM (1980) Divergent effects of prolactin upon steroidogenesis by porcine granulosa cells in vitro: influence on cytodifferentiation. Endocrinology $107,42-46$

Veldhuis JD, Nestler JE, Strauss III JF, Gwynne JT (1986) Insulin regulates low density lipoprotein metabolism by swine granulosa cells. Endocrinology 118, 2242-2253

Younglai EV (1972) The influence of follicular fluid and plasma on the steroidogenic activity of equine granulosa cells. $J$ Reprod Fertil 28 , 95-97

Webley GE, Luck MR, Hearn JP (1988) Stimulation of progesterone secretion by cultured human granulosa cells with melatonin and catecholamines. J Reprod Fertil 84, 669-677 